\title{
A Stroke of Genius? Religion, the Founding Fathers and the Creation of the American Polity
}

\author{
Herman T. Salton ${ }^{1}$ \\ ${ }^{1}$ Department of International Politics, University of Wales, Aberystwyth, UK \\ Correspondence: Dr Herman Salton, Department of International Politics, Room 3.25, University of Wales, \\ Penglais Campus, Aberystwyth SY23 3FE, UK. Tel: 44-197-062-1610.E-mail: hes3@aber.ac.uk
}

Received: August 27, 2012 Accepted: October 22, 2012 Online Published: April 24, 2013

doi:10.5539/par.v2n1p67

URL: http://dx.doi.org/10.5539/par.v2n1p67

\begin{abstract}
The place of religion in the United States has been hotly contested ever since the establishment of the American polity. This article revisits the origins of national identity in that country and argues that while religion played a crucial role in the formation of American consciousness, the wisdom of the US Founding Fathers lies in their decision to separate the public and private spheres - and to keep Church and State firmly divided. This was not, it should be noted, because they regarded the State to be more important than the Church, but rather because they thought that government was unworthy of interfering with religious faith and private conscience.
\end{abstract}

Keywords: America, religion, establishment clause, founding fathers, separation of church and state

\section{Introduction: Religion, History and Politics in the United States}

Historically, America's relationship with religion has been both close and complex, and it remains an issue of fierce debate. There are multiple sources of disagreement but the polarization usually involves clashes between those who depict the historical foundations of the country as being eminently religious (read Christian) and its population as particularly devout (Andrews, 1934; Carter, 1994), and those who claim that America is, and has always been, a secular State with secular institutions - and that this is precisely what makes it special (Rapp, 1991; Kramnick \& Moore, 1996). "Our civilization and our institutions are emphatically Christian", an American judge - and a proponent of the first school of thought — wrote in 1892. "From the discovery of this continent to the present hour", another wrote, "there is a single voice making the affirmation...that this is a Christian nation" (Safran, 2003: 13). Representatives of the second position, on the other hand, assert that "[i]t is not true that the Founders designed a Christian Commonwealth" (Kramnick \& Moore, 1996: 143), stating that "[t]he US Constitution... is a godless document. Its utter neglect of religion was no oversight; it was apparent to all" (Kramnick \& Moore, 1996: 27). The highly political character of this issue - and the frequent identification of these two positions with the two major parties in US politics - is not conducive to an objective debate; indeed, it heightens sensibilities and complicates the task of the impartial observer.

Both of these perspectives contain elements of truth, but like most generalizations they fail to acknowledge that the reality is not as clear-cut as it appears. Moreover, they neglect the importance of the distinction between the American nation (or community of people) and the American state (or political institution). When Alexis de Tocqueville, a French jurist-turned-politician, sailed to the United States in 1831 to study the democratic institutions of the newborn country, he was surprised by the centrality of religious conviction in society - and even more so by its intimate relation with democracy. "In the United States", he wrote in De La Démocratie en Amérique, "religion not only informs people's habits, but it even influences their way of thinking" (Tocqueville, 1986: 434). It was not that such an attachment to religion was absent in either Europe or France-quite the contrary, given the fact that most of Europe's wars had historically been religious conflicts. However, in Tocqueville's eyes, while religion meant freedom and democracy in the US, it meant tyranny and despotism in Europe. "In France I had seen the spirit of religion and the spirit of freedom marching almost invariably in opposite directions", he wrote. "Here [in America] I have found them intimately linked to each other: they both reign on the same soil" (Tocqueville, 1986: 437). The reason for this, the Frenchman concluded, was the remarkable separation of Church and State in America, in contrast to their incestuous relationship in Europe. "Everyone [in America] attributes their country's quiet empire of religion mainly to the complete separation of 
Church and State", he wrote. "I am not afraid to say that, during my stay in America, I have not met one person, religious or secular, who does not agree with this point." (Tocqueville, 1986: 437).

Tocqueville was writing just forty years after the French and American Revolutions, and at a time of considerable political and religious turmoil in France (Tocqueville, 1967). However, his analysis remains relevant as it draws attention to one of America's biggest contradictions: while it is arguably the most religious democracy in the world today, historically the US has done the most to maintain the separation of its spiritual beliefs and its socio-political institutions. Consequently, it has gone the farthest in its efforts to protect religious freedom (Safran, 2003: 13). In 1829, barely two years before Tocqueville's visit, the US Senate emphasized America's uniqueness precisely on the basis of the country's relationship with religion: the rest of the world was in "religious bondage", the Senate reported, and Europe's "scenes of persecution" and "cries of burning victims" were a painful reminder of precisely what path America should not take when it comes to religion (Kramnick \& Moore, 1996: 139-40). "Religious zeal", the Report concluded, "enlisting the strongest prejudices of the human mind..., excites the worst passions of our nature under the delusive pretext of doing God's service" (Kramnick \& Moore, 1996: 139-40). Look at Europe, the document seemed to say, and you will understand why America is special.

Things have not always been this way, however, and freedom of religion has not always been a characteristic of American society. Contrary to popular belief, religious freedom is not inherent to the United States.

\section{Religion, the Puritan Fathers and the Origins of the American Polity}

\subsection{From England to the New World}

There is an intimate relationship between religion and the founding of the American Nation, and some historians argue that the United States was born out of religious dissent (Cousins, 1958: 44; Ahlstrom, 1972: 37).

When Queen Elizabeth I ascended to the English throne in 1558, her first priority was to avoid the religious wars that were plaguing neighbouring France and that were threatening her own kingdom. In order to ensure stability and to circumvent the ferocious, and at times bloody, religious confrontations that had characterized the reign of the two previous Tudor monarchs, she re-established the Church of England as the official faith of the Empire. In 1571, she pushed an Act of Uniformity through parliament, calling for "one uniform order of common service and prayer, and of the administration of sacraments, rites and ceremonies in the Church of England" (Lambert, 2003: 40). She successfully quelled open religious confrontation but a number of Protestant dissidents found it increasingly difficult to live under the 'Elizabethan settlement'- that is to say, they were not content with supporting the Church of England in public worship in exchange for freedom of conscience in private beliefs. Consequently, a significant number of Protestants fled from England and its perceived religious oppression. They travelled to the newly discovered territories across the Atlantic in search of a virgin land where they could establish their own religious communities. Merchants, adventurers and other escapees soon followed: they varied in their spiritual allegiance and in other respects, but many held a common religious enthusiasm and the desire to establish new communities that reflected it (Lambert, 2003: 73).

Elizabeth I soon came to realize the economic and political significance of this movement of people, and before long began encouraging emigration and utilizing joint stock companies, entrepreneurs and individual proprietors as colonizers of the new land. Departing settlers were continuously reminded that their mission was based not only on God's will but also on the monarch's wishes, and that their enterprise was thus supported by both the Church and the State. "[King James I]", Anglican Minister William Symonds told a group of departing settlers, "in whom is the spirit of his great ancestor Constantine, the pacifier of the world and planter of the Gospel in places most remote, desireth to present this land a pure virgin to Christ" (Lambert, 2003: 39). The advantages for the English monarchs went far beyond financial profit, however, as colonization proved to be an extremely effective means of countering Catholic Spain's parallel migrations to the South of the newly discovered continent (Butler \& Stout, 1998). As one author summarizes, "[r]eligion in Tudor England was more than personal piety; it was power politics. And planting the Protestant faith in America was motivated by more than evangelical zeal; it was an instrument for checking Spain's expanding power"' (Lambert, 2003: 39).

Between 1607 and 1732 thirty-two colonies were established by English settlers in the new lands. Apart from its geopolitical significance, the arrival of English émigrés on American shores was a highly symbolic and emotionally-charged process. "They went to the New World as emissaries of Christ and subjects of their king", one author observed (Lambert, 2003: 39). The fact that these people left the known for the unknown and risked the long and perilous trip is indicative of their conviction in their divine mission; they sought to spread the word of God to the New World and to build a novel political and religious entity founded upon His words and example. While "[i]n 1492 Columbus had purported to represent the one and holy Catholic Church and thus 
claimed America for the Christian faith", one author commented, "English settlers vowed to make their settlements strongholds of the 'true' church, Protestant Christianity" (Lambert, 2003: 39).

Before leaving England, one group of travellers explicitly proclaimed the reasons for their journey and defined the contours of what they believed to be nothing less than a Covenant with the Almighty: "God hath taken us to be His after a most strickt and peculiar manner", they solemnly declared; "wee are entered into Covenant with Him for this worke, wee have taken out a Commission... Now if the Lord shall please to heare us, and bring us in peace to the place wee desire, then hath hee ratified this Covenant and sealed our Commission, [and] will expect a strickt performance of the Articles contained in it" (Kramnick \& Moore, 1996). The length and severity of the journey meant that many never made it to the New World, yet this only further affirmed the belief that their mission was truly biblical—something akin to the Exodus of the Holy Books. Thus, just as the Jews had fled Egypt in search of the promised land of Israel, the Puritan Fathers fled England with the conviction that they had been chosen by God for a new mission. They believed that because the Almighty had safely delivered them to the New World they were bound by the Covenant to establish a society governed by divine laws.

\subsection{Early-American Colonies and Marriage of Church and State}

As a result of the colonists' belief in the divinity of their mission, religion and politics visibly overlapped in many of the newly-established colonies. This 'Covenant with God' not only bound the settlers to the Almighty, but it also bound them to each other. Consequently, the strict and uncompromising enforcement of that legal and moral pact in the community was essential if God's wrath was to be avoided (Hawke, 1988). "The Lord has given us leave to draw our own articles", John Winthrop, the leader of the Massachusetts' Puritans, had unequivocally stated before leaving England- "[but] we have promised to base our actions on these ends...If we neglect to observe these articles...the Lord will surely break out in wrath against us and be revenged of such a perjured people, and He will make us know the price of the breach of such a covenant" (Lambert, 2003: 78).

At the outset at least, and with few exceptions, religious intolerance was the result. The Puritans had a divine mission to accomplish and they made sure that people either conformed to the rules or left. Moreover, these rules were strict: “...[E]veryone had to attend church", one author wrote, "people had to live in a family setting rather than singly, everyone had to learn to read in order to read the Bible, their personal behaviour and dress were carefully regulated, and they were expected to monitor each other's moral behaviour" (Chidester, 1988; 34). The 'City-Upon-A-Hill' had to be a sparkling, uncontaminated model of Christian faith and moral rectitude - in other words, it should be a symbol of what a people can achieve under the guidance of God. It is therefore unsurprising that its inhabitants were not particularly open-minded with regards to other religions. As has been aptly observed, "[t]he Puritans did not come to the New World to practice religious toleration; they came to practice their own religious views. [And they] did not believe in religious tolerance... They believed that only the truth should be heard and that it was dangerous and immoral to allow false religious ideas to be expressed" (Corbett \& Corbett, 1999).

Although each colony's experience varied according to the people who settled it, the rigorous and messianic approach of the 'City-Upon-A-Hill' soon translated into religiously-biased policies. Virginia was the first case in point (Greene, 1994: 238). Founded in 1607 and chartered by King James to propagate the "Christian religion to such people as yet live in darkness and miserable ignorance of the true knowledge and worship of God" (Lambert, 2003: 46), Virginia's colonization illustrates the fact that religious tolerance has not always been an American characteristic, and certainly demonstrates that it was not innate. When the new Governor, Lord De La Warr, arrived in Virginia in 1610, he immediately issued an order making it clear that correct religious practice was not a private and voluntary matter of conscience-it was a civic duty. "I do strictly commaund and charge all Captaines and Officers", he wrote, "to have a care that the Almightie God be duly and daily served....and that such, who shall often and willfully absent themselves, be duly punished according to the martial law in that case provided" (Lambert, 2003: 51). Things did not change with the advent of a legislative assembly, and in 1632 the General Legislature of Virginia passed a law-though religious order is perhaps a more appropriate term-stipulating that "there be a uniformitie throughout this colony both in substance and circumstance to the cannons \& constitutions of the Church of England as neere as may bee and that every person yield readie obedience unto them uppon penaltie of the paynes and fortfeitures in that case appoynted" (Lambert, 2003: 67).

Virginia was by no means an isolated case. Indeed, Massachusetts and Connecticut are further examples of the vital role played by religion in the organization of the new colonies. Founded in 1629 in order to establish a Christian Commonwealth, Massachusetts was the land of John Winthrop - the very man who coined the idea of the 'City-Upon-A-Hill' and who spelled out the contents of the 'Covenant with God' (Greene, 1994: 3). Like the Virginians, the Massachusetts' Puritans emphasized the sentiment that their holy experiment was not for 
everyone and that strict rules applied to religious observance-all in the name of the divine pact. As a consequence, Catholics and other dissenters such as Anglicans and Quakers were effectively excluded from the colony and practices such as witch trials, fines against Anabaptists, the exile of Antinomians and the physical punishment of heretics were by no means uncommon (Corbett and Corbett, 1996: 36). "To Puritans", one author observed, "intolerance in the name of Christian purity was not only defensible but mandatory for a covenanted people", because "[r] ligious freedom was defined as freedom from error" (Lambert, 2003: 75).

A similar approach inspired the New England Puritans who, in 1636, drafted the Fundamental Orders of Connecticut, the colony's new constitution (Greene, 1994: 131). The text made it clear that the Almighty was the sole source of government authority and that it was imperative for the new administration to pursue godly purposes. "The word of God", the text read, "requires that to mayntayne the peace and vnion of such people there should be an orderly and decent Government established according to God, to order and dispose of the affayres of the people" (Lambert, 2003: Note 19). As a matter of fact, the aim of the new government was "to mayntayne and presearue the liberty and purity of the gospel of our Lord which we now professe, as also the disciplyne of the Churches, which according to the truth of the said gospell is now practiced amongs vs" (Lambert, 2003: Note 19).

Thus, a major irony of this period of early American history was that the very same people who had rejected Europe's religious intolerance and fled the Old Continent in the name of religious freedom were establishing a system that, when it came to religious dissent, was anything but tolerant.

\section{Religion, the Founding Fathers and the Origins of the American State}

If the importance of religion in the founding of the first American colonies is relatively undisputed, the same cannot be said for its role in the eighteenth century, when the institutional basis of the new federal State was laid down. Indeed, a great deal of uncertainty exists over the position of religion in the establishment of America as a sovereign State. Considering the Founding Fathers' own ambiguity on the subject, this is hardly surprising. Before turning to that dilemma, however, we need to examine some important events that would affect the Framers' actions and convictions, as well as their opinions on the Church-State relationship.

\subsection{From Religious Intolerance to a Marketplace of Religions}

Between the early and mid-eighteenth century, something exceptionally important happened on the American continent - and once again it had to do with religion. Under the pressure of a series of circumstances which were both unpredicted and unpredictable, the ideals of spiritual compliance and religious orthodoxy that had underlined early settler communities started to crack (May, 1976: 42; Shuffelton, 1993: 205). This was a defining moment in American history and one which set apart the new country from the Old World most strikingly. While the causes of this transformation are multifarious, there are four key issues which can be identified as of significance: migration; the role of itinerant preachers and the First Great Awakening; unrest amongst the black population; and the effects of the Enlightenment.

\section{(i) Migration}

The eighteenth century witnessed a substantial increase in migration to the New World, and this to the extent that America soon became restless (Green \& Pole, 1984: 205). Migrants were leaving Northern Europe in ever-increasing numbers while goods were imported more frequently and people in the colonies themselves became more mobile, reacting to the population growth by settling down in places that were previously unpopulated. The result was soon visible. As Professor Frank Lambert explains, "Religious establishments and parish boundaries which had served reasonably well to preserve orthodoxy, now failed to contain new arrivals and their dissenting notions" (Lambert, 2003: 123). More people arrived in the country, more goods were being imported, more ideas were circulating and more religious freedom was being demanded (Finke \& Stark, 1992). That is to say, a migratory marketplace soon translated into a marketplace of goods, which created a marketplace of ideas, which further engendered a marketplace of religions. Of course this was not an instantaneous transformation, but it was rapid enough to cause concern within a Puritan generation unprepared for change (May, 1976: 105).

\section{(ii) Itinerant Preachers and the Great Awakening}

In the early stages of migration, the majority of those arriving in the New World were ordinary people. However, priests and ministers of a wide variety of faiths soon joined them and these itinerants became central to subsequent religious liberalization (Johnson, 1997: 283). These pastors, by travelling to different parishes and preaching in novel and innovative ways, brought about an environment of religious competition (Jones, 1992). After years of religious orthodoxy, people were highly receptive to different ideas and to the prospect of 
disagreeing. Consequently, the itinerants were extremely popular, parish boundaries were broken and the received thinking of conventional churches was destabilised (May, 1976: 105). This phenomenon, which is intimately connected to the First Great Awakening (Note 1), began to sweep across the American colonies in the 1730s and 1740s, leaving a permanent mark on what was to become the new Nation (Heimert and Miller, 1967). Breaking with the previous tradition of public ritual and ceremony, the Great Awakening transformed religion into an intensely personal affair, fomenting a sense of profound spiritual redemption. People became passionately and emotionally attached to their faith and were invited to participate in it actively, as opposed to the former, more inert and passive practice of listening to intellectual discourse. This proved to be crucial as it was this religious upheaval that laid the foundations for the political upheaval that was to follow.

\section{(iii) Slavery and Religion}

The relationship between relgion and slavery-and the growing unrest amongst the black population - constituted the third critical element of change (Dubois, 2003). Slave-ownership had been common practice in most colonies and the majority of established churches "defended slavery on religious, Christian grounds" (Safran, 2003: 18). "Rather than preaching the good news of emancipation and redemption", one author wrote, "ministers admonished slaves to be subservient and obedient, and to accept their lot in this life while hoping for a better life to come" (Lambert, 2003: 72). However, as the marketplace of ideas and religions gained momentum, this situation became potentially dangerous for the various churches. Whilst black slaves did not directly benefit from this mood of dissent, slave owners were nevertheless concerned that an increasing number of their subjects were embracing 'alternative' religious views.

These fears proved well-founded. It soon became clear that, for slaves, espousing the marketplace of religions was only one step away from espousing the marketplace of ideas - and consequently freedom. Since slaveholding had been systematically encouraged by most of the traditional churches, this would hardly have been a welcome development for the slave owners. As a result, the mantra that slaveholding was perfectly acceptable for a good Christian became even more insistent. "The right of holding slaves is clearly established in the Holy Scriptures, both by precept and example", a Baptist spokesperson declared in the 1770s (Corbett and Corbett, 1996: 95). Indeed, as late as 1864, southern Presbyterians were still arguing that "[i]t is the peculiar mission of the southern Church to conserve the institution of slavery" (Safran, 2003: 18). Arguably, slaveholders were mostly concerned that black people would begin to realise that "religion - religion of any kind - in the hands of power can be the worst kind of tyranny" (Bailyn, 2003: 5). Indeed, this sentiment echoed the thoughts of Thomas Jefferson, who ironically owned slaves himself (and had children by them). One of the greatest paradoxes of this time, however, was that this realisation was the result of the libratory effect of an expanding marketplace of religions (Note 2).

\section{(iv) The Enlightenment}

The significance of the Enlightenment in the development of a free marketplace of ideas in America cannot be overstated, and it constitutes the fourth crucial ingredient of change addressed here. John Locke's influence was particularly important: his vision of the human mind as a tabula rasa that takes in information, processes it and draws its own conclusions was as straightforward as it was revolutionary (Locke, 2002: 93). Simply put, it meant that human beings were in charge of their own knowledge and destiny, that they were autonomous and independent individuals capable of determining their own future. In an era dominated by superstition and revelation, this idea was revolutionary. "The business of law is not to provide for the truth of opinion", Locke wrote, "but for the safety and security of the commonwealth and of every particular man's goods and persons. The truth is not taught by law, nor has she any need of force to procure her entrance into the minds of men" (Kramnick \& Moore, 1996: 77-8). He concluded that "all the power of civil government relates only to men's civil interests, is confined to the care of the things of this world and hath nothing to do with the world to come" (Lambert, 2003: 184).

Radical as they were, Locke's ideas were intimately related to those of Francis Bacon and Isaac Newton, two other key pillars of the Enlightenment (Gooch, 1959). Like Locke, these theorists challenged the received thinking that had informed centuries of political thought-Bacon with his idea of knowledge as a big experiment (Bacon, 1854: 343), and Newton with his theory of the universe as a completely rational (and thus knowable) entity (Lambert, 2003: 161-3). As it was aptly observed, "[t]his [was] a critical turning point in Western culture as liberal ideology, very much influenced by Protestant conviction, pushe[d] morality and religion outside the public political realm to a private realm of individual preference. The entire definition of what is public and what is private [was] being changed" (Kramnick \& Moore, 1996: 75). Yet it is worth noting that this new vision did not mean that religion had to be rejected - quite the opposite. It simply meant that God and reason belonged to 
different domains. "A religious man, Newton did not see his new science as supplanting God", one author wrote. "Rather, he concluded that behind such a 'clockwise universe' there had to be an 'intelligent and powerful Being"” (Lambert, 2003: 166). Religion, in other words, was seen as an instrument of freedom rather than oppression - as part of the solution, rather than the problem — and it was precisely this mindset that the Founding Fathers enthusiastically embraced.

\subsection{The Founding Fathers, Religion and the First Amendment}

As has already been stated, the Founding Fathers' position on religion remains one of the most controversial issues of American history. The Framers have been depicted as modernizers and traditionalists (Botham, 2002: 33), brilliant and inconsistent (Bailyn, 2003: 33), principled and pragmatic (Corbett and Corbett, 1999: 62 and 83), atheists and fervent believers (Carter, 1994). Because they laid the foundations of the contemporary American edifice - and because this institutional masterpiece had scores of admirers and imitators in Europe and around the world (Lipset, 1973) - it is vital to understand the Framers' views on religion and its relationship with the State.

\section{(i) Religion's Role}

The Founding Fathers did not speak with a single voice; indeed, they represented a multifarious and heterogeneous corpus of people from a variety of backgrounds and cultural environments. However, one thing seems certain: they each attached importance to spirituality. This may seem surprising in light of the fact that they were to play a leading role in the construction of the first and most secular government ever established. However, this seeming contradiction is deceptive, for there is a critical difference between the importance of religion and its place in political life. The Framers certainly agreed that religion was important for the American people and for the Nation as a whole (Mead, 1975). John Adams wrote for example that "[a] common religion and virtue are the only foundation not only of republicanism and of all free government, but of social felicity under all governments and in all the combinations of human society. Without religion", he dryly concluded, "this world would be something not fit to be mentioned in polite company-I mean hell" (Witte, 2002: 1). The other Founders held similar views. Benjamin Franklin considered himself to be a person with "religious principles" (Witte, 2002: 176); George Washington belived that religion was "indispensable" and not "optional" (Hutson, 2002: 176); and Thomas Jefferson, who was considered the most 'deist' among the Founders, openly acknowledged that religion and morality were essential not only for a person but also for the State. "Can the liberties of a nation be thought secure when we have removed their only firm basis, a conviction in the minds of the people that these liberties are the gift of God?", he asked (Hutson, 2002: 164). Jefferson himself provided the answer when he uttered the following words to an acquaintance who was doubting his beliefs: "No nation has ever yet existed or been governed without religion. Nor can be. The Christian religion is the best religion that has ever been given to man and I, as Chief Magistrate of this nation, am bound to give it the sanction of my example" (Hutson, 2002: 159).

\section{(ii) Religion's Place}

Thus, most of the Founding Fathers acknowledged the importance of religion in a democratic society and they would have subscribed to Tocqueville's warning that "[i]t is despotism that may be able to exist without faith, not freedom" (Tocqueville, 1986: 436). But what about religion's place? This was the real issue. If it was true that religion in general - and the Christian religion in particular - were the source of freedom, democracy and justice as the Framers believed, should Christianity not then be officially enforced as a matter of state policy? It is in this that the originality of the Founding Fathers is situated: the answer was a resounding 'no', for a number of reasons.

Firstly, the majority of the Founders viewed religion in a special light, more in terms of religious rationalism or secular humanism than orthodox Christianity (Pennock and Chapman, 1988). They were sceptical about religious institutions and they believed that the State should refrain from interfering in people's spiritual beliefs. "I have ever thought religion to be a concern purely between our God and our consciences, for which we are accountable to Him, and not to the priests", Jefferson wrote (Kramnick \& Moore, 1996: 101). He further indicated that this is why there should be "an entire abstinence of the government from interference in any way whatever" (Kramnick \& Moore, 1996: 101). Jefferson was also a vocal critic of a number of Christianity's central beliefs: he thought that the true message of Jesus had been corrupted by religious institutions, and that the Bible itself had to be read with caution since it interspersed valuable moral teachings with pure superstition (Note 3). More significantly, Jefferson's idea of religion was extremely broad: as one author observed, for him “...good behaviour was more important than right belief. To him, morality was paramount to doctrine, and he thought that a moral society need not be a Christian one" (Lambert, 2003: 174). This was similar to what James 
Madison meant when he referred to "virtue" and "wisdom" (Bailyn, 2003: 34), and to John Adams" understanding that it was more than just faith that distinguished a good man from a bad one - it was his everyday conduct towards his fellow humans. "Adams believed that all good men (whatever their religious beliefs) were Christians", one author observed, which "is different from saying that a man had to be a Christian in order to be good" (Corbett and Corbett, 1999: 68).

Secondly, the Founding Fathers lived during a crucial period of American history. They were born after the Enlightenment and were deeply influenced by the writings of Locke, Bacon, Newton and other Illuminists. They believed that although God had created the universe, the individual — not the Almighty — was at the centre of it and was thus capable of determining his own destiny. In short, they were born in an age of reason, not theology. But their works, thoughts and actions were inevitably conditioned by the fact that America was a Christian country - and this is perhaps unsurprising given the fact that little more than a generation separated them from the time of the Puritan fathers. As late as 1720, most colonies still had established churches and the Virginia Statute for Religious Freedom - declaring religion to be free and voluntary-was only passed in 1785 . Thus the Framers lived through an extraordinary time: torn between tradition and innovation, they were the first to encounter America's greatest dilemma, namely, how to reconcile a Christian nation with religious freedom?

\section{(iii) The Founders' Solution: Separation and Religious Freedom}

The genius of the Founding Fathers lies precisely in their response to this question: a godless government by no means implied a godless America. It was not the importance of religion but rather its place in government that was contested by the Framers. In other words, their brilliance rests with the fact that they dared to reject the traditional principles of political thought and to question why things were the way they were. This was not an easy approach to take in this period and their actions did not pass by unchallenged. As Professor Bailyn reminds us, "[a]gain and again they were warned of the folly of defying the received traditions, the sheer unlikelihood that they, obscure people on the outer borderlands of European civilization, knew better than the established authorities that ruled them; that they could successfully create something freer, ultimately more enduring than what was then known in the centres of metropolitan life" (Bailyn, 2003: 4). Yet they were undeterred in their intellectual curiosity; for them, as for the Connecticut jurist Oliver Ellsworth, it was not enough to say that something must be so-“"[o]ne needs to know why. One needs 'some reason"” (Bailyn, 2003: 149).

Once they had asked 'why', the Framers concluded that sovereignty was not absolute and exclusive by nature. And so they did something unprecedented: they split that sovereignty between one federation and several states. They also determined that while God was the ultimate source of everything, men were in charge of their own actions and destiny, and again taking unprecedented steps, they separated the sovereignty of God (a matter for individuals and their churches) from the sovereignty of institutions (an issue for the civil government). The state, Jefferson wrote, should simply refrain "from intermeddling...with religious institutions, their doctrines, discipline, or exercises... and from the power of effecting any uniformity of time or manner among them" (Hutson, 2002: 2).

The result of these revolutionary ideas was a revolutionary constitution that guarantees freedom of religion but purposefully disregards religion itself. As the First Amendment of the US Constitution states, "Congress shall make no law respecting an establishment of religion, or prohibiting the free exercise thereof" (Mille, 1986). It thus constructed what Jefferson controversially defined as "a wall of separation between Church and State" (Hutson, 2002: 67). God was largely absent from the constitution (Note 4), and we are left to believe that had his inclusion been suggested, it would have met the same fate as the proposed reference to Christ in the Virginian Constitution: "The insertion was rejected by a great majority", Jefferson observed, "in proof that they meant to comprehend within the mantle of its protection the Jew and the Gentile, the Christian and the Mahometan, the Hindoo and infidel of every denomination" (Lambert, 2003: 238). This compromise of neutrality was reached partly because the Founders were aware of the considerable religious pluralism that existed in the different states; partly because they had seen the negative consequences of religious establishment in Europe and in their own land (as well as the way established churches treated dissidents); and partly because, like Tocqueville, they thought that secularism was the best way to preserve and promote religion itself (Tocqueville, 1986: 437).

However, the underlying reason for this compromise was that the Founding Fathers believed in - and were genuinely committed to-freedom. "The founders thought that people should be free to seek religious truth guided only by reason and the dictates of their consciences", one author observed, "and they determined that a secular State, supporting no religion but protecting all, best served that end" (Lambert, 2003: 167). In the marketplace of religions that characterised the American polity, the only way to ensure freedom for all was to guarantee the religious neutrality of the government, for "[ $[\mathrm{t}] \mathrm{he}$ same authority which can establish Christianity 
in exclusion of all other religions may establish with the same ease any particular sect of Christians" (Madison, 1939: 30-1).

\section{Conclusion: The Place of Religion in American History}

The fact that religion was seen by the Founding Fathers and by the American people as an instrument of freedom rather than oppression - and as part of the solution, rather than the problem - is one of the greatest lessons of American history (Heimert, 1966).

Unlike in Europe and in the early-English colonies, religion in the United States was associated with liberty from the beginning, contributing significantly to the American Revolution and to the origins of the American polity (Hatch, 1991). As one author has suggested, religious feelings and the Great Awakening were "the beginning of America's identity as a nation as well as the starting point of the Revolution" (McLoughlin, 2005: 77). Why? Because the therapeutic importance of the latter had been strongly encouraged by religion and not consistently hampered by it, as in the case of France. This was most famously expressed by John Adams when, in 1818, he wrote that "[t]he Revolution was effected before the war commenced. [It] was in the minds and hearts of the people, a change in their religious sentiments of their duties and obligations" (Adams, 1946: 203).

Although in the United States the 'religious question' is still far from resolved, the world witnessed the Founding Fathers' commitment to the secularity of their newly established masterpiece as early as 1797 . Six years after the adoption of the First Amendment, an official document - the Treaty of Peace and Friendship between the USA and Libya - eloquently stated in its Article 11 that “...[t]he government of the United States of America is not in any sense founded on the Christian Religion..." (Lambert, 2003: 29). The fact that they managed to build a thoroughly secular edifice whilst simultaneously putting religious freedom at the very top of the Bill of Rights is arguably the most enduring legacy of the Founding Fathers.

\section{References}

Adams, J. (1946). In K. A. Niles, \& W. Peden (Eds.), The Selected Writings of John Quincy Adams. New York: Knopf.

Ahlstrom, S. E. (1972). A Religious History of the American People. New Haven: Yale UP.

Andrews, C. M. (1934). The Colonial Period of American History: The Settlement. New Haven: Yale UP.

Bacon, F. (1854). Novum Organum. In B. Montague (Ed.), The Works (Vol. 3). Philadelphia: Parry \& MacMillan.

Bailyn, B. (2004). To Begin The World Anew: The Genius and Ambiguities of the American Founders. New York: Knopf.

Botham, D. H. (2002). George Washington: Uniting a Nation. New York: Rowman and Littlefield.

Butler, J., \& Stout, H. S. (Eds.) (1997). Religion in American History: A Reader. Oxford: Oxford UP.

Carter, S. L. (1994). The Culture of Disbelief. New York: Anchor Books.

Chidester, D. (1988). Patterns of Power: Religion and Politics in American Culture. New York: Prentice Hall.

Corbett, M., \& Corbett, J. M. (1999). Politics and Religion in the United States. New York: Garland.

Cousins, N. (1958). The Religious Beliefs and Ideas of the American Founding Fathers. New York: Harper;

Dubois, P. (2003). Slaves and Other Objects. Chicago: University of Chicago Press.

Finke, R., \& Stark, S. (1992). The Churching of America, 1776-1990: Winners and Losers in Our Religious Economy. New Brunswick: Rutgers University Press.

Gooch, G. P. (1959). English Democratic Ideas in the Seventeenth Century. New York: Harper.

Green, J. P., \& Pole, J. R. (1984). Colonial British America: Essays in the New History of the Early-Modern Era. Baltimore: John Hopkins University Press.

Greene, J. P. (1994) Negotiating Authorities: Essays in Colonial Political and Constitutional History. Charlottesville: University of Virginia Press.

Hatch, N. O. (1991). The Democratization of American Christianity. New Haven: Yale University Press.

Hawke, D. F. (1988). Everyday Life in Early America. New York: Harper and Row.

Heimert A., \& Miller, P. (Eds.) (1967). The Great Awakening: Documents Illustrating the Crisis and Its Consequences. New York: Bobbs-Merrill. 
Heimert, A. (1966). Religion and the American Mind. Cambridge, MA: Harvard UP.

Heyman, C. L. (2000). The First Great Awakening. Delaware: University of Delaware Press.

Hutson, J. H. (2002). Religion and the New Republic: Faith in the Founding of America. Oxford: Rowman and Littlefield.

Johnson, P. (1997). A History of the American People. New York: HarperCollins.

Jones, M. A. (1992). American Immigration. Chicago: University of Chicago Press.

Kramnick, I., \& Moore, L. (1996). The Godless Constitution. New York: Norton.

Lambert, F. (2003). The Founding Fathers and the Place of Religion in America. Princeton: Princeton UP.

Lipset, M. (1973). The First New Nation: The United States in Comparative Perspective. New York: Norton.

Locke, J. (2002). The Second Treatise of the State of Nature and a Letter Concerning Toleration. New York: Dover.

Madison, J. (1939). Writings. New York: Harper, New York.

May, H. F. (1976). The Enlightenment in America. New York: Oxford UP.

McLoughlin, W. (2005). In S. P. Huntington (Ed.), Who Are We? America's Great Debate. London: Free Press.

Mead, S. E. (1975). The Nation with the Soul of a Church. New York: Harper and Row.

Miller, W. L. (1986). The First Liberty: Religion and the American Republic. New York: Knopf.

Pennock, J. R., \& Chapman, J. W. (1988). Religion, Morality and the Law. New York: New York University Press.

Rapp, S. (1991). God's Country: A Case against Theocracy. New York: Haworth Press.

Safran, W. (2003). The Secular and the Sacred: Nation, Religion and Politics. London: Frank Cass.

Schaff, P. (1961). America: A Sketch of Its Political, Social and Religious Character. Cambridge, MA: Harvard UP.

Shuffelton, F. (1993). The American Enlightenment. New York: University of Rochester Press.

Tocqueville (de), A. (1967). De l'Ancient Régime et la Révolution. Paris: Gallimard.

Tocqueville (de), A. (1986). De La Démocratie en Amérique. Paris: Gallimard, Volume 1.

Ward Smith, J., \& Jamison, A. L. (1961). Religious Perspectives in American Culture. Princeton: Princeton UP.

Witte, J. (2002). A Most Mild and Equitable Establishment of Religion. In J. H. Hutson (Ed.), Religion and the New Republic: Faith in the Founding of America. Oxford: Rowman and Littlefield.

\section{Notes}

Note 1. The Great Awakening was a revitalization of religious piety that ran through America from the 1730s until the 1770s. As one author has observed, it consisted of the emergence of "a new Age of Faith to counter the currents of the Age of Enlightenment, to reaffirm the view that being truly religious meant trusting the heart rather than the head, prizing feeling more than thinking, and relying on biblical revelation rather than human reason" (Heyman, 2000: 17). This article is a revised version of my Veiled Threats? Islam, Headscarves and Religious Freedom in America and France (2008). All translations are mine.

Note 2. It is precisely this marketplace of religions that a number of authors regard as the peculiar characteristics which make America different from Europe (See e.g. Schaff, 1961; Ward Smith and Jamison, 1961).

Note 3. Perhaps the most radical among the Framers when it came to scepticism of religious institutions was Thomas Paine, whose views were as lapidary as they were abrasive: "I do not believe in the creed professed by the Jewish church", he wrote, "by the Roman Church, by the Greek Church, by the Turkish Church, by the Protestant Church, nor by any Church that I know of. My own mind is my own Church" (Lambert, 2003: 175).

Note 4. This is controversial, however. See for instance the following: "The framers erected a secular constitutional structure, which was then undermined as God entered first the US currency in 1863, then the federal mail service in 1912 and finally the Pledge of Allegiance in 1954” (Kramnick \& Moore, 1996: 143). 